\title{
Actualización 2009 del Calendario Nacional de Vacunación de la República Argentina
}

National Schedule Argenine Vaccination: 2009 update

Agustín Ciapponi *

El Ministerio de Salud de la República Argentina ha publicado el nuevo Calendario Nacional de Vacunación', destacándose tres nuevas incorporaciones:

1. Vacuna triple bacteriana acelular contra difteria, tétanos y pertussis para todos los adolescentes de once años de edad y el personal de salud.

La incidencia de la enfermedad por Bordetella pertussis ha aumentado en la mayoría de las jurisdicciones de nuestro país, registrándose la mayor morbimortalidad en los menores de seis meses. La fuentes de contagio en los menores de seis meses suelen ser los adultos jóvenes (hermanos, madre, padre, cuidadores). Un control adecuado de foco, administrando quimioprofilaxis y completando los esquemas de vacunación cuando estén indicados, tiene como objetivo disminuir la circulación de la Bordetella pertussis y el contagio a los lactantes pequeños.

2. Vacunación contra la fiebre amarilla para toda persona a partir del año de edad que habite en áreas de riesgo y a los viajeros que ingresan $o$ salen de zonas endémicas o epidémicas.

Zonas de riesgo recientemente definidas para la fiebre amarilla - Todos los departamentos de Misiones y Formosa.

- Departamento de Bermejo en Chaco.

- Departamentos de Berón de Astrada, Capital, General Alvear, General Paz, Ituzaingó, Itatí, Paso de los Libres, San Cosme, San Miguel, San Martín y Santo Tomé en la Provincia de Corrientes.

- Departamento de Valle Grande, Ledesma, Santa Bárbara y San Pedro en la Provincia de Jujuy.

- Departamento de General José de San Martín, Oran, Rivadavia y Anta en la Provincia de Salta.

Tabla 1: calendario nacional de vacunación de la república argentina.

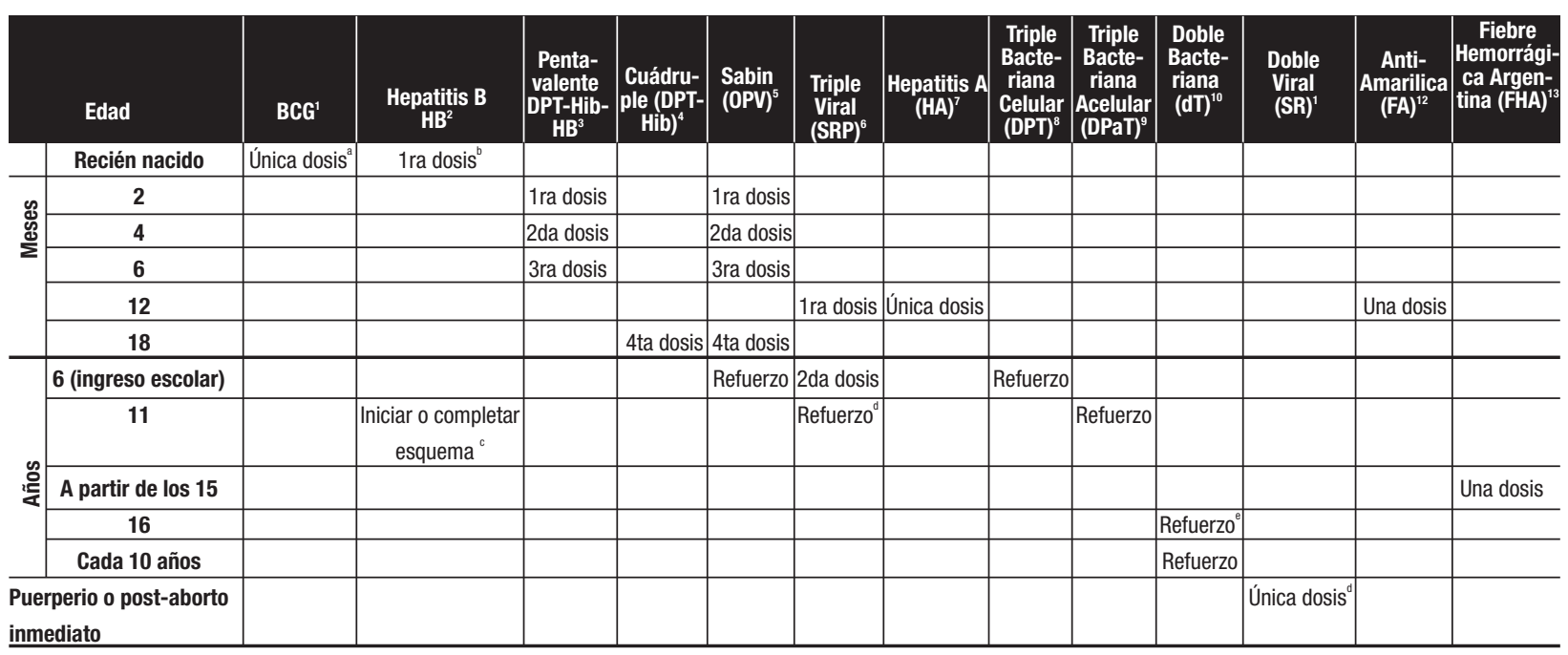

${ }^{a}$ Antes de egresar de la maternidad. ${ }^{\text {b }}$ Durante las primeras 12 horas de vida. c Si no recibió el esquema de la infancia, aplicar la primera dosis, la segunda dosis al mes de la primera y la tercera, a los seis meses de la primera. ${ }^{\mathrm{d}}$ Triple viral o Doble viral: si no recibió previamente dos dosis de triple viral, aplicar una dosis de doble viral. ${ }^{e}$ El refuerzo de Doble Bacteriana es solo para aquellos que iniciaron el esquema con DPT, al grupo que ingreso en el plan con DPaT (la triple bacteriana acelular) le corresponderá este refuerzo a los 21 años (y cada 10 años)

1) BCG o Tuberculosis. 2) HB o Hepatitis B. 3) DPT-HB-Hib o Pentavalente Difteria, Tétanos, Pertussis, Hepatitis B, Haemophilus Influenzae b. Los nacidos despues de Febrero de 2009 recibirán la vacuna quíntuple bacteriana a los dos, cuatro, y seis meses de vida, en lugar de aplicar cuadruple y Hepatitis B por separado. El esquema se completará con cuádruple y triple a los 18 meses e ingreso escolar respectivamente. 4) DPTHib o Cuádruple: difteria, tétanos, pertussis, Haemophilus influenzae b. 5) OPV o Sabin: vacuna antipoliomelítica oral. 6) SRP o Triple viral: sarampión, rubéola, parotiditis. 7) HA ó Hepatitis A: una sola dosis. 8) DPT o Triple bacteriana: difteria, tétanos, pertussis. 9) DPaT o Triple Bacteriana Acelular: a los 11 años. 10) dT o Doble bacteriana: difteria, tétanos. 11) SR o Doble viral: sarampión, rubéola. 12) FA o Fiebre Amarilla: una dosis para viajeros o residentes en zona de riesgo, con un refuerzo cada diez años. 13) FHA o Fiebre hemorrágica argentina: una dosis para viajeros o residente en zonas de riesgo.

Recibido el 06/07/09 y aceptado el 11/07/09

Referencia

1. Calendario Nacional de Vacunación de la República Argentina (2009). Disponible en: http://www.msal.gov.ar/htm/site/pdf/calendario-vac.pdf

* Servicio de Medicina Familiar y Comunitaria del Hospital Italiano de Buenos Aires. agustin.ciapponi@hospitalitaliano.org.ar 